\title{
GUT MORPHOMETRICS IN THE LONG-TAILED DUCK CLANGULA HYEMALIS WINTERING ON THE POLISH BALTIC COAST
}

\author{
EWA DZIAŁA-SZCZEPAŃCZYK
}

Department of Zoology, Agricultural University, 71-460 Szczecin, 20 Judyma Street, Poland.

Corresponding author: e-mail: ewa.dziala-szczepanczyk@biot.ar.szczecin.pl

\begin{abstract}
The study included guts of 140 individuals of the long-tailed duck Clangula hyemalis obtained in autumn and winter of 1993-2000 in the western part of the Polish Baltic Coast. The following morphometric characters were analysed: duodenum length (DL), combined jejunum and ileum length (JIL), small intestine length (SIL), combined terminal intestine and cloaca length (TCL), and combined length (CBL) and weight $(\mathrm{CBW})$ of both caeca. In the analysis the birds' sex and age were taken into consideration, as well as their body size characterised by body weight, body length, and sternum length. Ontogenetic differences in the gut morphometric characters were more pronounced in males than in females, and immature drakes were characterised by higher average values of JIL and CBW, compared to adult males. Besides the CBL and CBW, sexual dimorphism was manifest in the body size and other gut measurements - those parameters achieved higher average values in males than in females. No such differences were recorded with respect to relative parameters: DL, SIL, and TCL expressed as the percentage of the birds' body length. In case of JIL, CBL, and CBW no relation with any of the body size parameters was found. No relevant relations between SIL and JIL, and the measurements of CBL and TCL were noticed.
\end{abstract}

Key words: long-tailed duck Clangula hyemalis, gut, morphometry

\section{INTRODUCTION}

Many studies on the morphology of the bird alimentary tract show a strict relation of digestive organs with the kind and amount of food consumed. Such a relation was found during interspecific comparisons among members of the orders Passeriformes (Pulliainen et al., 1981; Richardson and Wooller, 1986, 
1990; Wooller and Rochardson, 1988; Ricklefs, 1996), Charadriiformes (Piersma et al., 1993), Galliformes (Leopold, 1953; Moss, 1974, 1983; Thomas, 1984), and Anseriformes (Kehoe and Ankney, 1985, Barnes and Thomas, 1987; Goudie and RYAN, 1991). Moreover, as shown by many observations and experiments with some species of the Galliformes (Anderson, 1972; Moss, 1972; SAvory And Gentle, 1976; Hanssen, 1979; Pulliainen and Tunkkari, 1983), Passeriformes (Ankney and Scott, 1988; Brugger, 1991) and Anseriformes (Miller, 1975; Ankney, 1977; Paulus, 1982; Drobney, 1984; Halse, 1984, 1985; Whyte and Bolen, 1985; Kenoe et al., 1988; Ankney and Afton, 1988), the bird digestive system changes through time under the influence of many factors, such as parasite invasion, seasonal changes in the diet, or hormonal reasons. Those factors, as well as birds' age, sex, and body size may result in individual variation in the digestive organs' structure. This variation is manifest, among others, in morphometric features - particularly clearly in the longest section of the alimentary tract, which is the gut.

The purpose of this paper is the morphometric characteristics of the gut of the long-tailed duck Clangula hyemalis in relation to bird size, sex and age.

The long-tailed duck belongs to the order Anseriformes, suborder Anseres, family Anatidae, subfamily Anatinae and tribe Mergini (Del Hoyo et al., 1992). It is a Holarctic species, during the breeding season living on lakes, slowflowing rivers in areas situated on the northern fringes of Eurasia, North America, Greenland, and the islands of the Arctic Ocean (Tomiatojć, 1990; DEL Hoyo et al., 1992). At that time it mainly feeds on animal food with addition of plants (algae, grass-blades, seeds, and other parts of tundra plants). The European population winters on the Baltic, North, and Black Seas. In this period the birds eat almost exclusively food of animal origin - mainly crustaceans and molluscs, to a lesser extent fish, insects and their larvae, and sporadically parts of plants (Madsen, 1954; Goudie and Ryan, 1991; Jamieson et al., 2001; Bustnes and Systad, 2001).

\section{METHODS}

The material for the study included guts of 140 individuals of the longtailed duck - 87 males ( 9 young and 78 adults) and 53 females (13 young and 40 adults). The birds were obtained in winter and spring of 1992-2000 from the Western part of the Polish Baltic coast - the area of Świnoujście, Międzyzdroje, Międzywodzie and Dziwnów (18 specimens in December, 19 in January, 53 in February, 10 in March and 40 in April).

Dead birds were taken from fishing nets - the animals got tangled in the nets and suffocated when diving for food. They were divided in two age groups (separately for each sex) - immature birds under 1 year old and adult birds over 1 year old. The age was determined based on the appearance of the tertiary flight feathers, wing covers, and the size of bursa Fabricii (GLick, 1983). Three measurement of the body size were taken: body length (BL), measured from the 
tip of the beak to the end of the rump (soft tape, accuracy $0.5 \mathrm{~cm}$ ); sternum length (SL), measured with a vernier calliper gauge, accuracy $0.5 \mathrm{~mm}$, according to Dziubin and Cooch's (1992) suggestion; and body weight (BW), accuracy 50 g. During post mortem the whole gut was removed, unfolded, the mesentery and fat tissue were removed and the gut was straightened, without tightening, and the length of its individual sections was measured (LEopolD's method, 1953). The duodenum, which is the initial section of small intestine up to flexura duoedenojejunalis, was measured after separation, to the nearest $0.5 \mathrm{~cm}$. The combined jejunum and ileum length (JIL) and combined terminal intestine and cloaca length (TLC) were measured to the nearest $0.5 \mathrm{~cm}$. The combined length of both caeca - left and right (CBL) was measured with $0.1 \mathrm{~cm}$ accuracy, and the weight of both those organs $(\mathrm{CBW})-$ to the nearest $0.01 \mathrm{~g}$. The small intestine length (SIL) was the combined length of duodenum, jejunum, and ileum.

The analysis of the data included examining relations between the body size parameters and the gut parameters, as well as parameters of particular organs. For this purpose, Pearson's linear correlation coefficients (r) were calculated. Indices describing relative sizes were calculated for those gut measurements which were statisticaly significantly dependent on any body size parameter. Significance of differences between the sexes and age classes were tested with t-Student test, with regard to the features describing their body size and average values of absolute and relative measurements of individual parts of the gut.

\section{RESULTS}

Mean values of the body size parameters and the absolute gut parameters are presented in Tables 1 and 2. In the examined group of 140 birds the mean small intestine length was $1656 \mathrm{~mm}$, the mean length of both caeca $-170 \mathrm{~mm}$, and the combined mean length of terminal intestine and cloaca $-93.5 \mathrm{~mm}$. No significant differences in body size were found between adult and immature individuals, among either males or females - only adult drakes showed larger body length than immature males. Ontogenetic differences in gut parameters of males were manifest the jejunum and ileum length, the caeca weight, and in the terminal intestine and cloaca length. In females, however, such differences were found only in the caeca length (Tab. 1).

Sexual dimorphism in the examined group of birds was very clearly expressed in the body size and the analysed gut parameters. The drakes were heavier; they had longer body and longer sternum than the ducks. The linear gut parameters also achieved higher values in males, compared to females. Only in the caeca length and weight no distinct differences were found between the sexes (Tab. 2).

Out of six analysed gut parameters, three (combined length of jejunum and ileum, combined length and weight of both caeca), showed no relation with any of the three body size parameters (Tab. 3). 
Table 1

Differences in absolute body and intestine parameters between immature and adult individuals of the long-tailed duck Clangula hyemalis (M - males, F - females, ad - adult individuals, im - immature individuals, $\bar{x}$ - arithmetic average, SD - standard deviation, CV - coefficient of variation, $t$ - values of t-Student's statistics, NS - differences statistically insignificant, $\mathrm{p}$ - level of significance).

\begin{tabular}{|c|c|c|c|c|c|c|}
\hline \multirow{2}{*}{$\begin{array}{l}\text { Measu- } \\
\text { rements }\end{array}$} & \multicolumn{2}{|c|}{$\begin{array}{l}\bar{x} \pm \mathrm{SD} \\
\mathrm{CV}(\%)\end{array}$} & \multirow{2}{*}{$\begin{array}{c}\mathrm{M}_{\mathrm{Ad}} \mathrm{Vs} . \\
\mathrm{M}_{\mathrm{Im}}\end{array}$} & \multicolumn{2}{|c|}{$\begin{array}{l}\bar{x} \pm \mathrm{SD} \\
\mathrm{CV}(\%)\end{array}$} & \multirow[t]{2}{*}{$\mathrm{F}_{\mathrm{Ad}}$ VS. $\mathrm{F}_{\mathrm{Im}}$} \\
\hline & $\begin{array}{c}\mathrm{M}_{\mathrm{Ad}} \\
\mathrm{n}=78\end{array}$ & $\begin{array}{c}\mathrm{M}_{\mathrm{Im}} \\
\mathrm{n}=9\end{array}$ & & $\begin{array}{c}\mathrm{F}_{\mathrm{Ad}} \\
\mathrm{n}=40\end{array}$ & $\begin{array}{l}\mathrm{F}_{\mathrm{Im}} \\
\mathrm{n}=13\end{array}$ & \\
\hline BW & $\begin{array}{c}978.9 \pm 65.3 \\
6.7\end{array}$ & $\begin{array}{c}980 \pm 68.2 \\
6.9\end{array}$ & NS & $\begin{array}{c}839 \pm 74.7 \\
8.9\end{array}$ & $\begin{array}{c}852.7 \pm 64.5 \\
7.7\end{array}$ & NS \\
\hline BL & $\begin{array}{c}363.1 \pm 9.6 \\
2.6\end{array}$ & $\begin{array}{c}356.1 \pm 9.3 \\
2.6\end{array}$ & $\begin{array}{c}\mathrm{t}=2.065 \\
\mathrm{p} \leq 0.05\end{array}$ & $\begin{array}{c}338 \pm 9.6 \\
2.8\end{array}$ & $\begin{array}{c}343 \pm 8.8 \\
2.5\end{array}$ & NS \\
\hline SL & $\begin{array}{c}101 \pm 6.0 \\
6.0\end{array}$ & $\begin{array}{c}98,6 \pm 5.7 \\
5.7\end{array}$ & NS & $\begin{array}{c}92.8 \pm 3.6 \\
3.9\end{array}$ & $\begin{array}{c}92.6 \pm 3.1 \\
3.4\end{array}$ & NS \\
\hline DL & $\begin{array}{c}254.8 \pm 25.9 \\
10.2\end{array}$ & $\begin{array}{c}241,7 \pm 39.2 \\
16.2\end{array}$ & NS & $\begin{array}{c}234.7 \pm 24.7 \\
10.5\end{array}$ & $\begin{array}{c}238.1 \pm 28.4 \\
11.9\end{array}$ & NS \\
\hline JIL & $\begin{array}{c}1423.8 \pm 143.7 \\
10.1\end{array}$ & $\begin{array}{c}1547.2 \pm 353.3 \\
22.8\end{array}$ & $\begin{array}{c}t=-2.008 \\
p \leq 0.05\end{array}$ & $\begin{array}{c}1369.2 \pm 134.9 \\
9,8\end{array}$ & $\begin{array}{c}1366.1 \pm 114.7 \\
8.4\end{array}$ & NS \\
\hline SIL & $\begin{array}{c}1676 \pm 152.1 \\
9.1\end{array}$ & $\begin{array}{c}1788.9 \pm 362.2 \\
20.2\end{array}$ & NS & $\begin{array}{c}1604 \pm 139.2 \\
8.7\end{array}$ & $\begin{array}{c}1604.2 \pm 119.7 \\
7.5\end{array}$ & NS \\
\hline CBL & $\begin{array}{c}170.4 \pm 28.6 \\
16.8\end{array}$ & $\begin{array}{c}175.7 \pm 25.0 \\
14.2\end{array}$ & NS & $\begin{array}{c}162 \pm 25.5 \\
15.7\end{array}$ & $\begin{array}{c}186.2 \pm 24.3 \\
13.1\end{array}$ & $\begin{array}{l}t=-3.003 \\
p \leq 0.0001\end{array}$ \\
\hline CBW & $\begin{array}{c}0.88 \pm 0.24 \\
27.1\end{array}$ & $\begin{array}{c}1,07 \pm 0.25 \\
23.2\end{array}$ & $\begin{array}{c}t=-2.352 \\
\mathrm{p} \leq 0.05\end{array}$ & $\begin{array}{c}0.87 \pm 0.24 \\
27.4\end{array}$ & $\begin{array}{c}1.01 \pm 0.29 \\
29.2\end{array}$ & NS \\
\hline TCL & $\begin{array}{c}97.4 \pm 11.0 \\
11.3\end{array}$ & $\begin{array}{c}88.5 \pm 9.7 \\
10.9\end{array}$ & $\begin{array}{c}t=2.331 \\
p \leq 0.05\end{array}$ & $\begin{array}{c}88 \pm 8.1 \\
9.3\end{array}$ & $\begin{array}{c}90.0 \pm 9.2 \\
10.2\end{array}$ & NS \\
\hline
\end{tabular}

BW - body weight $(\mathrm{g})$

$\mathrm{BL}$ - body length $(\mathrm{mm})$

$\mathrm{SL}$ - sternum length $(\mathrm{mm})$

DL - duodenum length $(\mathrm{mm})$

JIL - jejunum and ileum length $(\mathrm{mm})$

CBL - combined length of both caeca $(\mathrm{mm})$

CBW - combined weight of both caeca $(\mathrm{g})$

SIL - small intestine length intestinum tenue $(\mathrm{mm})$

TCL - combined length of intestinum terminale and cloaca $(\mathrm{mm})$

Linear correlation coefficients for most of the relations between the mean values of the gut parameters, calculated for the whole examined set of birds, had positive values. No significant relation of jejunum and ileum length and small intestine length to both caeca length was found (Tab. 3).

The values of the three analysed indices of relative gut length - duodenum length, combined jejunum and ileum length, and combined terminal intestine and cloaca length - did not differ significantly between the sexes (Tab. 4). 
Table 2

Differences in absolute body and oesophagus and intestine parameters between (M - males, F - female $\overline{x s}$, - arithmetic average, SD - standard deviation, CV - coefficient of variation, $\mathrm{t}$ - value of t-Student's statistics, NS - statistically insignificant differences, $\mathrm{p}$ - level of significance). Measurements symbols - see table 1 .

\begin{tabular}{|c|c|c|c|c|}
\hline \multirow{2}{*}{$\begin{array}{l}\text { Measure- } \\
\text { ments }\end{array}$} & \multicolumn{2}{|c|}{$\begin{array}{l}\bar{x} \pm \mathrm{SD} \\
\mathrm{CV}(\%)\end{array}$} & \multirow[t]{2}{*}{ M vs. F } & \multirow{2}{*}{$\begin{array}{c}\bar{x} \pm \mathrm{SD} \\
\mathrm{VC}(\%) \\
\mathrm{M}+\mathrm{F} \\
\mathrm{n}=140\end{array}$} \\
\hline & $\begin{array}{c}M \\
n=87\end{array}$ & $\begin{array}{c}\mathrm{F} \\
\mathrm{n}=53\end{array}$ & & \\
\hline \multirow[t]{2}{*}{$\mathrm{BW}$} & $979.0 \pm 65.2$ & $842.4 \pm 71.9$ & $\mathrm{t}=11.571$ & $927.3 \pm 94.8$ \\
\hline & 6.6 & 8.5 & $\mathrm{p} \leq 0.0001$ & 10.2 \\
\hline \multirow[t]{2}{*}{ BL } & $362.3 \pm 9.8$ & $339.2 \pm 9.6$ & $t=13.702$ & $353.6 \pm 14.8$ \\
\hline & 2.7 & 2.8 & $\mathrm{p} \leq 0.0001$ & 4.2 \\
\hline \multirow[t]{2}{*}{ SL } & $100.8 \pm 6.0$ & $92.8 \pm 3.5$ & $\mathrm{t}=8.805$ & $97.7 \pm 6.5$ \\
\hline & 6.0 & 3.8 & $\mathrm{p} \leq 0.0001$ & 6.6 \\
\hline \multirow[t]{2}{*}{ DL } & $253.4 \pm 27.6$ & $235.6 \pm 25.4$ & $\mathrm{t}=3.832$ & $246.7 \pm 28.1$ \\
\hline & 10.9 & 10.8 & $\mathrm{p} \leq 0.0001$ & 11.4 \\
\hline \multirow[t]{2}{*}{ JIL } & $1436.6 \pm 177.6$ & $1368.5 \pm 129.2$ & $\mathrm{t}=2.428$ & $1410.8 \pm 163.8$ \\
\hline & 12.3 & 9.4 & $\mathrm{p} \leq 0.05$ & 11.6 \\
\hline \multirow[t]{2}{*}{ SIL } & $1687.7 \pm 184.7$ & $1604.1 \pm 133.6$ & $\mathrm{t}=2.870$ & $1656.1 \pm 171.6$ \\
\hline & 10,9 & 8.3 & $\mathrm{p} \leq 0.001$ & 10.4 \\
\hline \multirow[t]{2}{*}{ CBL } & $171 \pm 28.13$ & $167.9 \pm 27.1$ & NS & $169.8 \pm 27.7$ \\
\hline & 16.4 & 16.1 & & 16.3 \\
\hline \multirow[t]{2}{*}{ CBW } & $0.89 \pm 0.24$ & $0.90 \pm 0.26$ & NS & $0.90 \pm 0.25$ \\
\hline & 27,3 & 28.6 & & 27.7 \\
\hline \multirow[t]{2}{*}{ TCL } & $96.5 \pm 11.2$ & $88.5 \pm 8.4$ & $\mathrm{t}=4.511$ & $93.5 \pm 10.9$ \\
\hline & 11.6 & 9.5 & $\mathrm{p} \leq 0.0001$ & 11.6 \\
\hline
\end{tabular}

Table 3 .

Coefficients of correlation for interdependents among linear measurment of intestine and parameters of body in long-tailed duck Clangula hyemalis (explanation to symbols see table 1).

\begin{tabular}{|c|c|c|c|c|c|c|c|c|}
\hline & BL & SL & DL & JIL & SIL & CBL & CBW & TCL \\
\hline BW & $0.76^{* * *}$ & $0.53 * * *$ & $0.40 * * *$ & NS & $0.23^{* *}$ & NS & NS & $0.44 * * *$ \\
\hline BL & - & $0.61 * * *$ & $0.33^{* * *} *$ & NS & $0.18^{*}$ & NS & NS & $0.39 * * *$ \\
\hline SL & & - & $0.20^{*}$ & NS & NS & NS & NS & $0.28 * * *$ \\
\hline DL & & & - & $0.17 *$ & $0.32 * * *$ & $0.25^{* *}$ & $0.23 * *$ & $0.25 * *$ \\
\hline JIL & & & & - & $0.98 * * *$ & NS & $0.23^{* *} *$ & NS \\
\hline SIL & & & & & - & NS & $0.26^{* *} *$ & NS \\
\hline $\mathrm{CBL}$ & & & & & & - & $0.47 * * *$ & $0.28 * * *$ \\
\hline CBW & & & & & & & - & NS \\
\hline
\end{tabular}

* $\quad$ - significant at $<0,05$

$* *$ - significant at $<0,01$

$* * *$ - significant at $<0,001$

NS - non-sinificant 
Table 4.

Relative parameters of the intestine of male and female of long-tailed duck Clangula hyemalis (as percent of body length), M - male, F - female, $\bar{x}$ - mean, s.d. - standard deviation, $\mathrm{CV}$ - coefficient of variation, $\mathrm{t}$ - Student test, $\mathrm{p}$ - significance level, NS - difference nonsignificant

\begin{tabular}{|c|c|c|c|c|}
\hline \multirow[t]{2}{*}{ Parameter } & \multicolumn{2}{|c|}{$\begin{array}{c}\bar{x} \pm \text { s.d. } \\
\mathrm{CV}\end{array}$} & \multirow[t]{2}{*}{ M vs. F } & \multirow{2}{*}{$\begin{array}{c}\bar{x} \pm \text { s.d. } \\
\text { CV } \\
\mathrm{M}+\mathrm{F} \\
\mathrm{n}=140\end{array}$} \\
\hline & $\begin{array}{c}M \\
\mathrm{n}=87\end{array}$ & $\begin{array}{c}\mathrm{F} \\
\mathrm{n}=53\end{array}$ & & \\
\hline DL/BL & $69.96 \pm 7.50$ & $69.49 \pm 7.66$ & NS & $69.78 \pm 7.54$ \\
\hline x $100 \%$ & 10.7 & 11,0 & & 10.8 \\
\hline SIL/BL & $466.16 \pm 53.73$ & $473.08 \pm 39.81$ & NS & $468.78 \pm 48.89$ \\
\hline x $100 \%$ & 11.5 & 8,4 & & 10.4 \\
\hline TCL/BL & $26.64 \pm 3.08$ & $26.08 \pm 2.34$ & NS & $26.43 \pm 2.83$ \\
\hline $\mathrm{x} 100 \%$ & 11.6 & 9,0 & & 10.7 \\
\hline
\end{tabular}

$\mathrm{DL} / \mathrm{BL}$ - relative length of duodenum

SIL/BL - relative length of small intestine

$\mathrm{TCL} / \mathrm{BL}$ - relative length of rectum and cloaca

\section{DISCUSSION}

The examined set of long-tailed ducks showed mean values of some gut parameters similar to those obtained in other studies on the species. Goude and RYAN (1991), examining 20 wintering individuals of the long- tailed duck, obtained the following results: mean small intestine length $-170.6 \mathrm{~cm}$ and mean length of both caeca $-201 \mathrm{~mm}$ at the mean body weight of $758.8 \mathrm{~g}$. In BARNES and Thomas's studies (1987) the weight of both caeca of 14 birds with the average body weight of $758.8 \mathrm{~g}$ was $0.61 \mathrm{~g}$. The values of gut parameters may be directly related to the kind of food cnsumed by the birds. During wintering the birds feed only on the material of animal origin, and moreover, as shown by Goudie and RyAn (1991), their diet is very diverse. Long-tailed ducks have rather long caeca for their body size, but their weight is not great. BARNES and Thomas (1987) found a relation between the caeca weight and the diet in the Anatidae: in herbivorous species these organs were heavier than in carnivorous and omnivorous species. For instance, the mean caecum weight in of the planteating ring-necked duck Aythya collaris, with the mean body weight comparable to that of the long-tailed duck, of $761 \mathrm{~g}$, was $0.93 \mathrm{~g}$, and in the omnivorous lesser scaup Aythya affinis, with the mean body weight of $705 \mathrm{~g}$, it was $1.08 \mathrm{~g}$ (Goudie and RYAN, 1991).

In the examined set of birds adult males differed in their body size from immature males - although they were bigger, they had shorter jejunum and ileum, and a smaller weight of both caeca. Adult females, not differing in their body size, had shorter caeca compared to immature females. A similar tendency was observed for immature males of mallard Anas platyrhynchos - although 
visibly smaller than adult drakes, they had longer small intestines (including jejunum and ileum). No such dependence was found in immature females of this species, which were also smaller than adult ducks (DziaŁa-SzczepańczyK, 2001).

The sexual dimorphism in the gut parameters of the examined long-tailed ducks was more distinct than the age-related differences. Larger males had distinctly longer parts of the gut (except caeca parameters) than females, which suggests differences in the size of this organ resulting from different body size of birds of opposite sexes. This assumption is confirmed by the comparison of relative values of some gut parameters. The duodenum length, combined jejunum and ileum length, and combined terminal intestine and cloaca length in relation to the body length did not significantly differ between males and females. Sexual dimorphism in the parameters of some gut sections parts was also observed in other bird species. Like the examined long-tailed ducks, mallard males had longer jejunum and ileum (and small intestine) compared to the smaller females (DZIAŁA-SZCZEPAŃCZYK, 2001). However, the relative lengths of duodenum, small intestine, terminal intestine and cloaca, expressed as the percentage of mallards' body length, did not significantly differ between the sexes (DziataSZCZEPAŃCZYK, 2001). In the red-necked grebe Podiceps griseigena, despite the distinct difference in body size in favour of males, no significant differences were found between the sexes in any of the analysed gut parameters (SZCZEPAŃCZYK 1999). Paulus (1982) reported different results in his studies on the wintering gadwall Anas strepera; the males had a significantly longer small and terminal intestines (in relation to their body weight) than females. In the studies by SzCZEPAŃCZyK et al. (2000), males of the bean goose Anser fabalis, which are larger than females, had a shorter small intestine, though the statistical significance of the difference was not determined. Longer intestine in smaller specimens (young and females) in some bird species may be due to different diets. StempNiewicz (1986), examining wintering velvet scoters Melanitta fusca, described a vast diversity of diets of males and females, and immature and adult individuals, e.g. adult drakes ate more fish than juveniles. However, females and males of wintering tufted duck Aythya fuligula differed not only in their preferences for certain bivalve species, but also in their size (Ока et al., 1999). The differences may result from different energy requirements of smaller individuals. This concept was put forward by PulLianen (1976), based on ther relatively small intestine and caeca lengths (in relation to body weight) in wintering willow grouse Lagopus lagopus. According to this author lighter birds (females and immature individuals) with longer intestines must consume more food than heavier individuals (males and adults) to survive at low temperatures. MiLLER (1974), in experiments on wild mallard Anas platyrhynchos in captivity, found that female gut was longer than the males gut, though the birds of both sexes were fed with the same food. He assumed that female mallards were more adpatable to changing diet.

The lack of significant relation of the jejunum and ileum length and both caeca length with the body size parameters, observed in this study, was also shown for the mallard (Dziaza-Szczepańczyk, 2001) and the velvet scoter 
(SZCZEPAŃCZYK, 1998), with respect to body length and weight. In the whitefronted goose (SzCZEPAŃCZYK et al., 1999) and bean goose (SZCZEPAŃCZYK et al., 2000) no relation was found between the length of both caeca and the body length and weight, and with tarsus length, whereas the combined jejunum and ileum length was positively correlated with the body weight in the two species. The lack of relation of caeca length and jejunum and ileum length with the body size may be attributed to the high plasticity of these organs, quickly adapting to a changing diet. In Miller's (1974) opinion the gut morphology in members of the genus Anas changes so quickly with the changing diet that its length can not be used as an indicator of the consumed food quality.

No significant relation was found in the long-tailed duck between the jejunum and ileum length and the caeca length, contrary to what was observed for the velvet scoter (SZCZEPAŃCZYK, 1998), white-fronted goose (SZCZEPAŃCZYK et al., 1999), and mallard (Dziaza-Szczepańczyk, 2001). In the bean goose (SZCZEPAŃCZYK et al., 2000) the length of both caeca was positively correlated with the combined jejunum and ileum length. Presumably, such divergent results referring to the relation of jejunum and ileum sizes with both caeca length in the mentioned anseriform birds species may indicate a different role performed by those parts of the gut in the digestive process in individual species, resulting from their different diets.

In the examined set of the long-tailed ducks no significant differences were observed between the length of the terminal intestine and cloaca vs. the length of the jejunum and ileum. Similarly, the carnivorous velvet scoter Malanitta fusca showed no such correlation (SzczEPANCZyK, 1998). However, in the omnivorous mallard Anas platyrhynchos, the length of the small intestine, jejunum and ileum was positively correlated with the length of the terminal intestine and cloaca (DZIA_A-SZCZEPAŃCZYK, 2001). Similarly, in the herbivorous white-frionted goose (SZCZEPańCZYK et al., 1999) and bean goose (SZCZEPAŃCZYK et al., 2000) a positive correlation was observed between the length of jejenum and ileum. It is likely that in omnivorous and herbivorous anseriform species the reaction of the two parts of intestine - small and terminal - to the changing fiber content is similar. In predatory ducks, for example long-tailed duck and velvet scoter, the length of the terminal intestine has no correlation with the length of the small intestine, probably due to the diet which is rich in calories and devoid of fiber.

\section{MORFOMETRIA JELITA LODÓWEK CLANGULA HYEMALIS ZIMUJĄCYCH NA POLSKIM WYBRZEŻU BAŁTYKU}

\section{STRESZCZENIE}

Morfometria jelita 140 osobników lodówki Clangula hyemalis objęła ustalenie długości: dwunastnicy, jelita czczego i krętego, jelita cienkiego, jelita końcowego oraz długości i masy obydwu jelit ślepych. Uzyskane wyniki analizowano przy 
uwzględnieniu płci, wieku i wielkości ciała ptaków (opisanej trzema parametrami: masą i długością ciała oraz długością mostka). Różnice ontogenetyczne zaznaczyły się wyraźniej w grupie samców niż w grupie samic, przy czym młode kaczory cechowały się dłuższym jelitem czczym i krętym oraz cięższymi jelitami ślepymi niż dorosłe osobniki tej płci. Wykazany dymorfizm płciowy w wielkości ciała ptaków zaznaczył się również w większości pomiarów jelita. Oprócz pomiarów jelit ślepych wszystkie pozostałe części jelita osiagały większą długość u samców niż u samic. Nie nie stwierdzono istotnych różnic między kaczorami i kaczkami we względnej długości: dwunastnicy, jelita cienkiego i krętego oraz jelita końcowego (wyrażonej jako procent długości ciała ptaków). W przypadku trzech pomiarów: długości jelita czczego i krętego, masy oraz długości obydwu jelit ślepych nie odnotowanego związku z żadnym spośród parametrów opisujących wielkość ciała lodówek. Nie wykazano istotnych zależności między długością jelita czczego i krętego oraz długością jelita cienkiego a długością obydwu jelit ślepych oraz długością jelita końcowego.

\section{REFERENCES}

Anderson, W. L., 1972: Dynamics of condition parameters and organ measurements in Pheasants. Ilinois Nat. Hist. Surv. Biull., 30: 443-498.

Ankney, C. D., 1977. Feeding and digestive organ size in breeding Lesser Snow Geese. Auk, 94: 275-282.

Ankney, C. D. and Afton, A. D., 1988: Bioenergeticcs of breeding Northern Shovelers: diet, nutrient reserves, clutch size, and incubation. The Condor, 90: 459-472.

Ankney, C. D. and Scott, D. M., 1988: Size of digestive organs in breeding Brownheaded Cowbirds, Molothrus ater, relative to diet. Can. J. Zool., 66: 1254 $-1257$.

Barnes, G. G. and Thomas, V. G., 1987: Digestive organ morphology, diet and guild structure of North American Anatidae. Can. J. Zool., 65: 1812-1817.

Brugger, K. E. 1991: Anatomical adaptations of the gut to diet in Red-winged Blackbird (Agelaius phoeniceus). Auk, 108: 562-567.

Bustnes, J. O. and Systad, G. H., 2001: Comparative feeding ecology of Steller's Eider and Long-tailed Ducks in winter. Waterbirds., 24(3): 407-412.

Drobney, R. D., 1984: Effect of diet on visceral morphology of breeding Wood Ducks. Auk, 101: 93-98.

DzIAŁa-SzczepańczyK, E., 2001: [Morphometric characteristic of the intestine in Mallard Anas platyrhynchos and the Domestic Duck of Peking type Anas platyrhynchos f. domestica] Zesz. Nauk. Przeg. Hod. PTZ, 57: 77- 85. (in Polish with English summary).

Dziubin, A. and Cooch, E., 1992: Measurement of Geese: General Field Methods, California Waterfowl Association. Sacramento, CA. 20pp.

Glick, B., 1983: Bursa of fabricius. [in: Avian biology Farner D. S., King J. R., Parkes K. C., Vol. VII] Academik Press London.

Goudie, R. I and Ryan, P. C., 1991: Diets and morphology of digestive organs of five species of ducks wintering in Newfoundland. J. Yamashina Inst. Ornithol. 22: $1-8$. 
Halse, S.A., 1984: Diet, body condition, and gut size of Egiptian Gesse. J. Wildl. Manage. 48(2): 569-572.

Halse, S.A., 1985: Diet and size of the digestive organs of Spur-winged Geese. Wildfowl 36: 129-134.

HANSSEN, I., 1979: Micromorphological studies on the small intestine and caeca in wild and captive Willow Grouse (Lagopus lagopus lagopus). Acta vet. Scand. 20: 351-364.

Hoyo, J., del Eilliott, A. and Sargatal, J. (eds),, 1992: Handbook of the Birds of the World. Vol. Lyn. X Edition, Barcelona.

Jamieson, S. E., Robertson, G. J. and Gilchrist, H. G., 2001: Autumn and winter diet of Long-tailed Duck in the Belcher Islands, Nunavut, Canada. Waterbirds., 24(1): 129-132.

Kehoe, F. P. and Ankney, C. D., 1985: Variation in digestive organ size amomg five species of diving ducks (Aytha spp.) Can. J. Zool., 63: 2339-2342.

Kehoe, F.P., Ankney, C.D. and Alisaushas, C.D., 1988: Effect of dietary fiber and diet diversity on digestive organs of captive mallards (Anas platyrhynchos). Can. J. Zool., 66: 1597-1602.

LEOPOLD, A.S., 1953: Intestinal morphology of gallinaceous birds in relation to food habits. J. Wildl. Manage.,17(2): 197-203.

Madsen, F.J., 1954: On the food habits of the diving ducks in Denmark. Copenhagen.

Miller, M.R., 1974: Digestive capabilities, gut morphology, and cecal fermentation in wild waterfowl (genus Anas) fed various diets. M. S. Thesis. Univ. California, Davis. 87 pp.

Miller, M.R., 1975: Gut morphology of mallards in relation to diet quality. J. Wildl. Manage., 39(1): 168-173.

Moss, R., 1972: Effects of captivity on gut lengths in Red Grouse. J. Wildl. Manage., 36(1): 99-104.

Moss, R., 1974: Winter diets, gut lengths, and interspecific competition in Alaskan ptermigan. Auk, 91: 737-746.

Moss, R., 1983: Gut size, body weight, and digestion of winter food by Grouse and Ptarmigan. Condor, 85: 185-193.

Oka, N., Yamamuro, M., Hiratsuka, J. and Satoh, H., 1999: Habitat selection by wintering tufted ducks with special reference to their digestive organ and to possible segregation between neighboring populations. Ecological Reseach, 14: $303-315$

Paulus, L.S., 1982: Gut morphology of Gadwalls in Louisiana in winter. J. Wildl Manage., 46(2): 483-489.

Piersma, T., Koolhaas, A. and Dekinga, A., 1993: Interactions between stomach structure and diet choice in shorebirds. Auk, 110: 552-564.

Pulliainen, E., 1976: Small intestine and caeca lengths in the willow grouse (Lagopus lagopus) in Finnish Lapland. Ann. Zool. Fennici, 13: 195-199.

Pulliainen, E., Helle, P and Tunkkari, P., 1981: Adaptive radiation of the digestive system, heart and wings of Turdus pilaris, Bombycilla garrulus, Sturnus Vulgaris, Pyrrhula pyrrhula, Pinicola enducleator and Loxia pytyopsittacus. Ornis Fenn., 58: 21-28.

Pulliainen, E. and Tunkkari, P., 1983: Seosonal changes in the gut length of the willow grouse (Lagopus lagopus) in Finnish Lapland. Ann. Zool. Fennici, 20: 53-56. 
Richardson, K. C. and Wooller, R.D., 1986: The structures of the gastointestinal tracts of Honeyeaters and other smal birds in relation to their diets. Aust. J. Zool., 34: 119-24.

Richardson, K.C. and Woollier, R.D., 1990: Adaptations of alimentary tracts of same Australian lorikeets to diet of pollen and nectar. Austr. J. Zool., 38: 581-586.

Ricklefs, R.E., 1996: Morphometry of the digestive tracts of some passerine birds. Condor, 98: 279-292.

Savory, C.J. and Gentle, M.J., 1976: Changes in food intake and gut size in Japanese Quail in response to manipulation of dietary fibre content. Br. Poult. Sci., 17: $571-580$.

Stempniewicz, L., 1986: The food intake of two Scoters Melanitta fusca and M. nigra wintering in the Gulf of Gdańsk, Polish Baltic coast. Vár Fágelv. Suppl., 11: 211-214.

SzCZEPAŃCZYK, E., 1998: [Morphometry of digestive canal of the Velvet Scoter Melanitta fusca], Zesz. Nauk. Przeg. Hod. PTZ 36: 35-42 (in Polish with English summary).

SZCZEPAŃCZYK, E.,1999: [Morphometry and morphology of the digestive canal in the Red-Necked Grebe Podiceps griseigena] Zesz. Nauk. Przeg. Hod. PTZ, 45: 99-109 ( in Polish with English summary).

Szczepańczyk, E., Kalisińska, E., Ligocki, M. and Bartyzel, B., 1999: Morphometry of gut in the White-fronted Goose Anser albifrons. Adv. Agr. Scien., 6: 79-90.

Szczepańczyk, E., Kalisińska, E., Ligocki, M. and Bartyzel, B., 2000: Morphometry of esophagus and gut in Bean goose Anser fabalis. Zool. Polon., 45/1-4: 37-46.

Thomas, D.H., 1984: Winter diet and intestional proportions of rock and willow ptermigan and sharp-tailed grouse in Ontario. Can. J. Zool., 62. 1984.

TomiaŁojć, L., 1990: [Birds of Poland: Distribution and Numbers] PWN, Warsaw. Poland (in Polish).

Whyte, R.J. and Bolen, E.G., 1985: Variation in mallard digestive organs during winter. J. Wildl. Manage., 49(4): 1037-1040.

Wooler, R.D. and Richardson, K.C., 1988: Morphological relationship of passerine birds from Australia and New Guinea in relation to their diet. Zool. J. Linn. Soc., 94: 193-201. 